\title{
Study of Marketing Education Communication in Increasing the Capability of Mismes to Survive in the Time of Covid 19 Pandemic: Digital Literature Perspective
}

\author{
Riesso Andi Sawe ${ }^{1, *}$, K. A. Sumarlin ${ }^{2}$, Rahmawati ${ }^{3}$, Rachmawaty ${ }^{4}$ \\ ${ }^{1}$ Department of Management, Sekolah Tinggi Ilmu Ekonomi Pembangunan Indonesia,Makassar, Indonesia \\ ${ }^{2}$ Department of Management, Sekolah Tinggi Ilmu Ekonomi Pembangunan Indonesia,Makassar, Indonesia \\ ${ }^{3}$ Department of Management, Sekolah Tinggi Ilmu Ekonomi Pembangunan Indonesia,Makassar, Indonesia \\ ${ }^{4}$ Department of Management, Sekolah Tinggi Ilmu Ekonomi Pembangunan Indonesia,Makassar, Indonesia \\ ${ }^{*}$ Corresponding author Email: andisaweriesso@stie-pi.ac.id
}

\begin{abstract}
The examination on the Impact of the COVID-19 Pandemic on Small and Medium Enterprises was led subjectively, the reason for subjective exploration was to clarify a peculiarity as profoundly as conceivable by gathering the most unfathomable information, which shows the significance of profundity and detail of the information being considered. The spread of this infection affects all MSME entertainers in Indonesia and straightforwardly affects the intense decrease in the MSME economy, a great deal of MSMEs have left business despite the fact that there are still some MSMEs that can in any case get by, specifically MSMEs that by and large produce purchaser labor and products that are near their necessities.
\end{abstract}

Keywords: MSMEs, Impact of the Covid 19 Pandemic.

\section{INTRODUCTION}

The Covid 19 pandemic has had a significant effect, particularly on the manageability of the MSME (Small and Medium Enterprises) business. In light of the information gathered, $96 \%$ of MSME entertainers professed to have encountered the adverse consequence of Covid 19 in their business processes. It was additionally viewed that as $75 \%$ of them encountered the effect of a decrease in deals and deals. experience vulnerability in getting admittance to crisis reserves. This additionally affects the restricted tasks of MSMEs and less customers who shop straightforwardly contrasted with ordinary days., buying and advertising items by using gadgets [1].

In the review [2] and [3] presumed that online business impacts further developing the promoting execution and pay of MSMEs. As well as conveying web based business exchanging, MSME entertainers are additionally needed to have the option to impart items seriously by advertising items utilizing computerized showcasing and using online media to have the option to arrive at buyers straightforwardly and diminish special expenses.

Research led [4] uncovers that showcasing exercises, particularly during the pandemic, can make monetary worth [5]. The financial worth can decide the cost of an item. As well as zeroing in on esteem, purchasers will likewise modify mindfulness [6].

Research uncovered a decrease in MSME capital of up to $60 \%$ because of this constant pandemic. However, not a couple of them were at long last ready to rise and recuperate to confront the pandemic. The recuperated MSME entertainers are the people who can adjust to the conditions during the pandemic and afterward make plans and carry out new techniques in carrying on with work. This examination will look at and make studies identified with the maintainability of the MSME Business and E-Commerce as a commercial center device upheld by computerized promoting [7]. 


\section{LITERATURE REVIEW}

Correspondence is a social interaction that happens between somewhere around two individuals where somebody sends a specific number of images to other people. In the interim, as per [7] the thought of promoting is the method involved with giving fulfillment to purchasers for benefit. From the two definitions above, it tends to be reasoned that the thought of promoting correspondence is a correspondence action pointed toward passing on messages to purchasers and clients by utilizing various media and different channels that can be utilized with the expectation of three phases of progress, to be specific: changes in information, changes in perspectives, and Changes in wanted activity [8] say that advertising correspondence plans to accomplish three phases of progress focused on buyers, in particular the principal phase of Knowledge Change, the second phase of Attitude Change and the third social part 22 (goal to purchase). The methodologies in conquering the monetary emergency or the effect of the Covid-19 pandemic so MSME entertainers can endure are:

a. Improve Product and Service Quality

b. Utilize Technology Optimally

Online Media Marketing With such countless webbased media clients today, web-based media advertising is likewise a powerful procedure for business achievement. Web-based media advertising is a technique for advancing (promoting) items or administrations utilizing different online media stages, like Instagram, Facebook, or Youtube. MSMEs can utilize one of the online media stages that are generally utilized by their customers. Assuming that the objective customer is more seasoned, then, at that point, Instagram can be utilized, however in the event that the objective customer is bigger, then, at that point, Facebook is a more proper web-based media to utilize.

\section{METHOD}

Table 1. Concept variables

\begin{tabular}{|c|c|}
\hline Concept & Indicator \\
\hline \multirow[t]{3}{*}{$\begin{array}{c}\text { Marketing } \\
\text { communication }\end{array}$} & $\begin{array}{l}\text { 1. Types of marketing } \\
\text { communication }\end{array}$ \\
\hline & $\begin{array}{l}\text { 2. Marketing communication } \\
\text { model }\end{array}$ \\
\hline & $\begin{array}{l}\text { 3. Purpose of marketing } \\
\text { communication }\end{array}$ \\
\hline
\end{tabular}

\begin{tabular}{cll}
\hline Strategies to & 1. $\begin{array}{l}\text { Improve product and service } \\
\text { quality } \\
\text { Improve }\end{array}$ & 2. Make the most of \\
Ability to & $\begin{array}{l}\text { technology } \\
\text { Survive in the }\end{array}$ & Dovid-19 \\
$\begin{array}{c}\text { Condemic } \\
\text { Period }\end{array}$ & & \\
\hline
\end{tabular}

\section{DISCUSSION}

The Covid-19 pandemic has changed the conduct of the two customers and makers. This adjustment of conduct can't be isolated from the guidelines during the pandemic that power people to do physical removing. This multitude of limits in the end likewise genuinely affect financial specialists. One more effect experienced by MSME entertainers is very genuine, information ordered from [9] states that just 5.9\% of MSMEs can benefit during the pandemic. The excess $82.9 \%$ were contrarily impacted.

The effect doesn't stop there. Some SMEs have encountered a decrease in their turnover. Of the 37 thousand MSMEs in the information, 63.9\% encountered a decrease in turnover $>30 \%$. In the interim, another $31.7 \%$ encountered a decline in turnover between $0-30 \%$.

The present circumstance shows that the business world is not doing so great. This condition can't be isolated from the decrease in their turnover. Computerized Marketing MSMEs Expansion of clients in having the option to pass through different entryways. Business entertainers can likewise make new clients from the organizations they have done. Advanced showcasing through web-based media is one of the entryways for growing expected clients. Research led [10] uncovers that the utilization of advanced showcasing media can build client reliability. The capacity of MSMEs to make due during this pandemic isn't just upheld by great monetary administration yet in addition by their transformation system. The variation made by MSME entertainers is identified with the utilization of computerized showcasing offices to build mindfulness, empowering shoppers to review the brand of an item. Moreover, customers will make moment buys utilizing the commercial center.

Purchasers will settle on moment purchasing choices quicker when the item being advanced utilizations a computerized advertising model and the products are accessible in the commercial center. MSME entertainers who comprehend this change, quickly adjust. The variation is identified with 
advancement and deals. This variation is one of the procedures to get by in the midst of vulnerability. The coherence of a MSME level business should make due to be lost from the market. Research [11] uncovers that a significant part in business congruity is the client. In his exploration, it was uncovered that client esteem in deciding business progression is $86 \%$ of the all out parts. Accordingly, holding clients and looking for new client extension is the most judicious methodology amidst a pandemic.

The maintainability of the MSME Business The Covid 19 pandemic is a troublesome time for MSMEs. However, that doesn't amount to nothing gets by or material develops. MSMEs that can get by and develop during this pandemic are the people who enter the computerized environment [7]. The advanced environment for this situation is the presence of a commercial center as a method for selling MSME items. The individuals who have taken on the business strategy utilizing a commercial center that can make due amidst a pandemic. The subsequent procedure did by MSMEs in endurance is to develop. The advancements they do don't stop at content or items. More than that, MSME business entertainers make changes or advancements as far as administration or serving. The presence of advanced highlights in the deals and advancement model can help deals and the degree of client mindfulness. Particularly in the event that the business is still somewhat new. A review led [11] uncovered that the utilization of computerized advertising utilizing web-based media expands the pay of a new company.

\section{ACKNOWLEDGMENTS}

We thank the anonymous reviewers who have provided constructive suggestions for improving this article.

\section{REFERENCES}

[1] Aliami, Sri., Ema Nurzainul H., Diah Ayu, and Septi Fauji. 2018. Dampak Pengembangan Pemasaran Digital Pada Startup's (Studi Kasus Pada Wirausaha Baru). Jurnal EkoNiKa 3(1): 7387.

[2] Bambang Arianto, 2020 Pengembangan UMKM Digital di Masa Pandemi Covid-19. Jurnal Administrasi Bisnis Vol. 6 No. 2 ,233-247

[3] Brown, Ross and Augusto Rocha. 2020. Entrepreneurial Uncertainty during the Covid-19 Crisis: Mapping the Temporal Dynamics of
Entrepreneurial Finance. Journal of Business Venturing Insights 14: 1-10.

[4] Kennedy, J. E. R., \& Soemanagara, D. (2016). Marketing Communication $\mathrm{n}$-Taktik dan Strategi. PT Buana Ilmu Populer (kelompok Gramedia.

[5] Kotler, P., \& Amstrong, G. (2012). Manajemen Pemasaran. Erlangga.

[6] Kotttler, P., \& Amstrong, G. (2016). Dasar-dasar Pemasaran (Kesembilan). Erlangga.

[7] Narulia, Ria Zulkha E. and Hanjar Ikrima Nanda. 2019. Digital Marketing Sebagai Strategi Pemasaran. Jurnal Pengabdian Untuk Mu NegeRI 3(2): 80-84.

[8] Octavia, Graceica and Wulan Purnama Sari. 2018. Bentuk Komunikasi Pemasaran Digital ST22 Consulting. Prologia 2(2): 339-46.

[9] Setyorini, D., Nurhayaty, E., \& Rosmita, R. (2019). Pengaruh Transaksi Online (e-Commerce) Terhadap Peningkatan Laba UMKM(Studi Kasus UMKM Pengolahan Besi Ciampea Bogor Jawa Barat). Jurnal Mitra Manajemen, 3(5), 501-509. https://doi.org/10.52160/ejmm.v3i5.228

[10] Shabrina, V. G. (2019). Pengaruh Revolusi Digital terhadap Pemasaran dan Perilaku Konsumen. Jurnal Pewarta Indonesia, 1(2), 131-141. https://doi.org/10.25008/jpi.v1i2.16

[11] Wan Laura Hardilawati1, 2020 The Survival Strategy Of Smes During The Covid-19 Pandemic,jurnal akuntansi dan ekonomika, 90-98. 